\title{
Coexistence of insomnia and chronic diseases in over 60 years olds
}

\author{
WERONIKA WOLIŃSKA ${ }^{A-F}$, IWONA EWA PAWLAK ${ }^{\mathrm{B}, \mathrm{D}, \mathrm{E}}, \mathrm{BOŻENA} \mathrm{MROCZEK}{ }^{\mathrm{A}}, \mathrm{D}, \mathrm{E}$ \\ Department of Human Sciences in Medicine, Pomeranian Medical University in Szczecin
}

A - Study Design, B - Data Collection, C - Statistical Analysis, D - Data Interpretation, E - Manuscript Preparation, $\mathbf{F}$ - Literature Search, $\mathbf{G}$ - Funds Collection

Summary Background. The coexistence of several chronic physical illness worsens and the body burden older people, causing both poor health and lower quality of life. Multidisease has a significant impact on the incidence of sleep disorders, including insomnia.

Objectives. The aim of this study was to determine how selected chronic diseases are related to insomnia and its severity in over 60 year old members of the University of the Third Age in Stargard.

Material and methods. The research was conducted among 131 persons aged 60 years and above, including $72.52 \%(n=95)$ women and $27.48 \%(n=36)$ men. The mean age was $68.12 \pm 6.63$. The survey was used with elements of Athens Insomnia Scale (AIS), Insomnia Severity Index (ISI) and author's own questionnaire with questions about taking sleeping pills.

Results. The most respondents was a arterial hypertension $53.43 \%(n=70)$ including $68.57 \%$ in women $(n=48)$, and $31.43 \%$ $(n=22)$ in men. The indicator of multidisease was a 1,25 per respondent. Insomnia was reported in persons with arterial hypertension $\left(\mathrm{Chi}^{2}=6.256 ; p=0.043\right)$, asthma and chronic obstructive $\left(\mathrm{Chi}^{2}=22.79 ; p=0.0001\right)$, atherosclerosis $\left(\mathrm{Chi}^{2}=8.368\right.$; $p=0.015)$ and depression $\left(\mathrm{Chi}^{2}=20.94 ; p=0.0002\right)$.

Conclusions. Insomnia in the group of members of the University of the Third Age in Stargard coexists with chronic diseases, such as hypertension, asthma/COPD, atherosclerosis and depression.

Key words: insomnia, chronic disease, multimorbidity, people after 60 year of age.

Fam Med Prim Care Rev 2016; 18(3): 364-367

\section{Background}

Sleep is necessary for health and proper functioning throughout the day. While being asleep, the organism rests, body tissues grow and rebuild [1]. In accordance with the Diagnostic and Statistical Manual of Mental Disorders, Fourth Edition (DSM-4), insomnia is a complaint of difficulty initiating or maintaining sleep or of inability to obtain enough sleep or restorative sleep [2]. Available studies show that we devote one third of our lives to sleeping, therefore its quality and influence on social and professional lives is so important [3]. Chronic, untreated sleep disorders have negative effects on both quality of life and the course of concomitant chronic diseases. They can make the prognosis less favorable, and hamper therapeutic process [4].

Researchers emphasize the risk of developing a dominoeffect, manifested by the fact that progressive damage to one internal organ entails a higher probability of adverse lesions in other organs. It can lead to multimorbidity and multi-organ insufficiency, and consequently to taking several medicines at the same time [5]. A factor that may lead to insomnia in geriatric people is polypragmasy that is unreasonable administration of many different remedies at the same time. Polypragmasy increases the risk of adverse drug interactions, which may result in insomnia $[6,7]$.

Multimorbidity is an essential contributor to sleep disorders, including insomnia $[8,9]$. Insomnia is a powerful predictor of the occurrence of cardiovascular diseases $[10,11]$. Chronic sleep deficiency is associated with incorrect functioning of the cardiovascular system. Conditions belonging to this group are hypertension and atherosclerosis [12]. The cardiovascular system is affected by changeability of the circadian rhythm [13]. Some reports suggest that there are changes in sleep stages and sleep structure of patients with hypertension. These changes cause that patients wake up more frequently during the night and their sleep is not restorative [14].

Diabetic patients suffer from sleep disorders [15-17]. What play an important role in the course of diabetes is the circadian rhythm [18]. According to the available studies, inadequate amount of sleep can lead to glucose intolerance in humans [19]. It was proved that restorative sleep is significantly related to a blood glucose level, and the latter is negatively affected even by a single episode of sleepless night [20].

Depression is accompanied by sleep disorders. Among the criteria for the diagnosis of the so called episode of depression, are sleep problems, such as early morning awakening and inability to fall asleep again, as well as drowsiness during a day resulting in a lower mood [3]. Studies indicate that insomnia is the most common sleep disorder among patients suffering from depression [16, 21-23]. It may be a sign of upcoming depression or approaching remission [24].

\section{Objectives}

The aim of this study was to determine how selected chronic diseases are related to insomnia and its severity in over 60 year old members of the University of the Third Age in Stargard.

\section{Material and methods}

Respondents were randomly recruited from the members of the University of the Third Age in Stargard due to the fact that this group have not yet been analyzed with regard 
to sleep disorders. The criterion for inclusion to the study was at least 60 years of age. The surveyed participated in the study voluntarily. The research instruments used in this survey-based study were: the Athens Insomnia Scale (AIS), the Insomnia Severity Index (ISI), and the authors' questionnaire providing information about socioeconomic data, chronic diseases and using hypnotic drugs. The AIS consists of eight insomnia-related questions, each answered on a four-point scale and scored $0-3$. The AIS total scores are interpreted as follows: $<5$ points - no insomnia, 6-10 - borderline insomnia, $>10$ points - insomnia. The ISI includes seven questions concerning the severity of insomnia, each answer being scored on a scale value of $0-4$. The cut-off scores for the ISI are: 0-7 - no clinically significant insomnia, 8-14 - subthreshold insomnia, 15-21 - clinical insomnia of moderate severity, 22-28 - clinical severe insomnia.

Pearson's chi-square test for independence was applied. The level of statistical significance was set at $p \leq 0.05$. Statistical analysis was performed using PQStat software and an Excel spreadsheet.

\section{Results}

The study involved 131 respondents from Stargard in West Pomeranian Voivodeship, including 95 women (72.52\%) and 36 men $(27.48 \%)$. The participants were aged $60-85$ years (mean age: $68.12 \pm 6.63)$. Few respondents $(11.45 \%$; $n=$
15) declared using hypnotic drugs, such as herbal remedies and prescription drugs (no names given) (Tab. 1).

\begin{tabular}{|l|l|}
\hline \multicolumn{2}{|l|}{ Table 1. Characteristics of the study sample } \\
\hline Variable & $n(\%)$ \\
\hline Number of respondents & $131(100 \%)$ \\
\hline $\begin{array}{l}\text { Sex: } \\
\text { women } \\
\text { men }\end{array}$ & $95(72.51 \%)$ \\
\hline $\begin{array}{l}\text { Age [years]: } \\
\text { X SD } \\
\text { min. } \\
\text { max. }\end{array}$ & $36(27.48 \%)$ \\
\hline $\begin{array}{l}\text { Marital status: } \\
\text { married } \\
\text { widowed } \\
\text { single }\end{array}$ & $68.12 \pm 6.63$ \\
\hline $\begin{array}{l}\text { Education: } \\
\text { primary } \\
\text { vocational } \\
\text { secondary } \\
\text { higher }\end{array}$ & 60 years \\
\hline $\begin{array}{l}\text { Using hypnotic drugs: } \\
\text { yes }\end{array}$ & $83(63.35 \%)$ \\
no & $41(31.29 \%)$ \\
\hline
\end{tabular}

${ }^{1}$ Arithmetic mean $\pm \mathrm{SD}$ (minimum and maximum range).

\begin{tabular}{|c|c|c|c|c|c|c|}
\hline \multirow[t]{3}{*}{ Chronic diseases } & \multirow{3}{*}{$\begin{array}{l}\text { Number of } \\
\text { respondents } \\
{[n]}\end{array}$} & \multirow[t]{3}{*}{$(\%)$} & \multicolumn{4}{|c|}{ Sex } \\
\hline & & & \multicolumn{2}{|c|}{ women } & \multicolumn{2}{|c|}{ men } \\
\hline & & & $n$ & $(\%)$ & $n$ & $(\%)$ \\
\hline Diabetes & 24 & $18.32 \%$ & 17 & $70.83 \%$ & 7 & $29.17 \%$ \\
\hline Hypertension & 70 & $53.43 \%$ & 48 & $68.57 \%$ & 22 & $31.43 \%$ \\
\hline Asthma/COPD & 22 & $16.79 \%$ & 20 & $90.91 \%$ & 2 & $9.09 \%$ \\
\hline Atherosclerosis & 19 & $14.50 \%$ & 14 & $73.68 \%$ & 5 & $26.32 \%$ \\
\hline Depression & 12 & $9.16 \%$ & 9 & $75 \%$ & 3 & $25 \%$ \\
\hline Others & 18 & $13.74 \%$ & 16 & $89.89 \%$ & 2 & $11.11 \%$ \\
\hline
\end{tabular}

\begin{tabular}{|l|l|l|l|l|l|}
\hline \multirow{2}{*}{ Table 3. Insomnia vs. chronic diseases } & \multirow{2}{*}{ Chi $^{2}$} & \multirow{2}{*}{$\boldsymbol{p}$} \\
\cline { 1 - 5 } & \multicolumn{2}{|l|}{$\begin{array}{l}\text { Athens Insomnia Scale (AIS) } \\
\text { no insomnia } \\
n(\%)\end{array}$} & $\begin{array}{l}\text { borderline insomnia } \\
n(\%)\end{array}$ & $\begin{array}{l}\text { insomnia } \\
n(\%)\end{array}$ & \\
\hline Diabetes & $8(33.3 \%)$ & $6(25 \%)$ & $10(41.6 \%)$ & 3.368 & 0.185 \\
\hline Hypertension & $26(37.1 \%)$ & $21(30 \%)$ & $23(32.8 \%)$ & 6.256 & $\mathbf{0 . 0 4 3}$ \\
\hline Asthma, COPD & $3(13.6 \%)$ & $4(18.1 \%)$ & $15(68.1 \%)$ & 22.79 & $\mathbf{0 . 0 0 0 1}$ \\
\hline Atherosclerosis & $4(21 \%)$ & $5(26.3 \%)$ & $10(52.6 \%)$ & 8.368 & $\mathbf{0 . 0 1 5}$ \\
\hline Depression & $2(16.6 \%)$ & - & $10(83.3 \%)$ & 20.94 & $\mathbf{0 . 0 0 0 2}$ \\
\hline Other chronic diseases & $3(16.6 \%)$ & $8(44.4 \%)$ & $7(38.8 \%)$ & 8.204 & $\mathbf{0 . 0 1 6}$ \\
\hline
\end{tabular}

\begin{tabular}{|c|c|c|c|c|c|c|}
\hline \multirow[t]{2}{*}{ Chronic diseases } & \multicolumn{3}{|c|}{ Insomnia Severity Index (ISI) } & \multirow[b]{2}{*}{$\begin{array}{l}\text { severe insomnia } \\
n(\%)\end{array}$} & \multirow[t]{2}{*}{$\mathrm{Chi}^{2}$} & \multirow[t]{2}{*}{$p$} \\
\hline & $\begin{array}{l}\text { no insomnia } \\
n(\%)\end{array}$ & $\begin{array}{l}\text { subthreshold } \\
\text { insomnia } n(\%)\end{array}$ & $\begin{array}{l}\text { moderate } \\
\text { insomnia } n(\%)\end{array}$ & & & \\
\hline Diabetes & $11(45.83 \%)$ & $11(45.83 \%)$ & $2(8.33 \%)$ & - & 0.688 & 0.875 \\
\hline Hypertension & $25(35.71 \%)$ & $36(51.43 \%)$ & $8(11.43 \%)$ & $1(1.43 \%)$ & 8.436 & 0.037 \\
\hline Asthma, COPD & $3(13.64 \%)$ & $13(59.09 \%)$ & $6(27.27 \%)$ & - & 16.81 & 0.0007 \\
\hline Atherosclerosis & $4(21.05 \%)$ & $9(47.37 \%)$ & $5(26.32 \%)$ & $1(5.26 \%)$ & 11.49 & 0.009 \\
\hline Depression & $2(16.67 \%)$ & $8(66.67 \%)$ & $2(16.67 \%)$ & - & 5.505 & 0.138 \\
\hline Other chronic diseases & $5(27.78 \%)$ & $11(61.11 \%)$ & $2(11.11 \%)$ & - & 4.036 & 0.257 \\
\hline
\end{tabular}




\begin{tabular}{|c|c|c|c|c|c|}
\hline \multirow[t]{2}{*}{ Variable } & \multicolumn{3}{|c|}{ Athens Insomnia Scale (AIS) } & \multirow[t]{2}{*}{$\mathrm{Chi}^{2}$} & \multirow[t]{2}{*}{$p$} \\
\hline & $\begin{array}{l}\text { no insomnia } \\
n(\%)\end{array}$ & $\begin{array}{l}\text { borderline insomnia } \\
n(\%)\end{array}$ & $\begin{array}{l}\text { insomnia } \\
n(\%)\end{array}$ & & \\
\hline \multicolumn{6}{|c|}{ Using hypnotic drugs } \\
\hline Use & $2(13.33 \%)$ & $3(20 \%)$ & $10(66.66 \%)$ & \multirow[t]{2}{*}{13.782} & \multirow[t]{2}{*}{0.001} \\
\hline Don't use & $60(51.72 \%)$ & $30(25.86 \%)$ & $26(22.41 \%)$ & & \\
\hline
\end{tabular}

\begin{tabular}{|c|c|c|c|c|c|c|}
\hline \multirow[t]{2}{*}{ Variable } & \multicolumn{4}{|c|}{ Insomnia Severity Index (ISI) } & \multirow[t]{2}{*}{$\mathrm{Chi}^{2}$} & \multirow[t]{2}{*}{$p$} \\
\hline & $\begin{array}{l}\text { no insomnia } \\
n(\%)\end{array}$ & $\begin{array}{l}\text { subthreshold } \\
\text { insomnia } n(\%)\end{array}$ & $\begin{array}{l}\text { moderate } \\
\text { insomnia } n(\%)\end{array}$ & $\begin{array}{l}\text { severe insomnia } \\
n(\%)\end{array}$ & & \\
\hline \multicolumn{7}{|c|}{ Using hypnotic drugs } \\
\hline Use & $1(6.66 \%)$ & $8(53.33 \%)$ & $5(33.33 \%)$ & $1(6.66 \%)$ & \multirow[t]{2}{*}{18.80} & \multirow[t]{2}{*}{0.0003} \\
\hline Don't use & $61(52.58 \%)$ & $46(39.65 \%)$ & $8(6.89 \%)$ & $1(0.86 \%)$ & & \\
\hline
\end{tabular}

The most numerous were respondents with hypertension $53.43 \%(n=70)$; those with diabetes constituted $18.32 \%$ $(n=24)$, including $70.83 \%(n=17)$ of women and $29.17 \%$ $(n=7)$ of men (Tab. 2). The respondents mentioned also 'other' chronic diseases, such as atrial fibirillation, arrhythmia, degenerative joint disease $-13.74 \%$ of the surveyed $(n=18)$, including $89.89 \%$ of women $(n=16)$ and $11.11 \%$ of men $(n=2)$. The average number of diseases per one respondent was 1.25.

We analyzed the relationship between the occurrence of insomnia and reported chronic diseases (Tab. 3). No statistically significant relationship was observed between diabetes and insomnia $\left(\mathrm{Chi}^{2}=3.368 ; p=0.185\right)$. There were strong relationships between asthma/COPD and insomnia $\left(\mathrm{Chi}^{2}=\right.$ $22.79 ; p=0.0001$ ), and between depression and insomnia $\left(\mathrm{Chi}^{2}=20.94 ; p=0.0002\right)$.

We analyzed the connection between the severity of insomnia and reported chronic diseases (Tab. 4). Statistically significant relationship was demonstrated between the severity of insomnia, and asthma/COPD $\left(\mathrm{Chi}^{2}=16.81 ; p=\right.$ 0.007). The respondents with asthma and COPD more often suffered from subthreshold insomnia.

A statistically significant relationship between insomnia and the use of hypnotic drugs is shown in Table $5\left(\mathrm{Chi}^{2}=\right.$ $13.782 ; p=0.001)$. Hypnotic drugs were taken by $11.45 \%$ $(n=15)$ of the respondents. Over $22 \%(n=26)$ of patients with insomnia did not use hypnotic drugs. More than $66 \%$ ( $n$ $=10$ ) of the respondents taking hypnotic drugs continued to suffer from insomnia, and over $13 \%$ of the surveyed $(n=2)$ taking hypnotic drugs had no insomnia according to the AIS.

The relationship between the severity of insomnia and the use of hypnotic drugs is shown in Table 6. People suffering from insomnia significantly more often took hypnotic drugs $\left(\mathrm{Chi}^{2}=18.80 ; p=0.0003\right)$.

\section{Discussion}

Insomnia and other sleep disorders can occur as a consequence of chronic diseases [8]. We analyzed insomnia and its severity with respect to selected diseases, such as diabetes, hypertension, asthma/COPD, atherosclerosis, depression and others. The aim of our study was to determine the relationship between selected chronic diseases and insomnia and its severity among over 60 year old members of the University of the Third Age in Stargard.

Our findings did not demonstrate a significant relationship between diabetes and insomnia. Insomnia was diagnosed in about $41 \%$ of the respondents with diabetes. Different outcomes were obtained by Jakitowicz et al. [25] who analyzed 67 respondents at the average age of 67.36 years, and observed insomnia in over $70 \%$ of the patients with diabetes. In the study of Plantinga et al. [26] and Cunha et al. [27], almost $90 \%$ of diabetic patients had sleep problems.

We found that the presence of hypertension was statistically significantly related to insomnia and its severity. Nearly $33 \%$ of the surveyed with hypertension had insomnia according to the AIS. Similar results were obtained by Piwoński et al. [28] in the study Pol-Monica Bis, in which over $40 \%$ of the respondents with hypertension had insomnia. The research, conducted by Błaszczyk et al. [29] in a sample of 1003 individuals, demonstrated a statistically significant relationship between sleep disorders and hypertension.

In our study, insomnia was diagnosed in almost $70 \%$ of the respondents suffering from asthma and COPD. The result was statistically significant. Moderate insomnia was observed in more than $30 \%$ of asthma patients. More than $50 \%$ of the respondents with atherosclerosis had insomnia confirmed by the AIS. Less than $30 \%$ of the surveyed had moderate insomnia. Literature does not provide reports concerning similar issues.

Insomnia was noted in over $80 \%$ of the patients with depression, which was statistically significant. Ohayon et al. [30] reported that $65 \%$ of people with depression battled against insomnia.

The outcomes of our study indicated that hypnotic drugs were taken by one tenth of the respondents, which means that only a small proportion of them searched for pharmacological solutions. As stated by Siemiński et al. [9], hypnotic drugs were used by $10 \%$ of the respondents. These results were supported by Chrzan and Kulpa [31], who analyzed a sample of 200 patients at the average age of 78.3 years, and found that only $9 \%$ of them took hypnotic drugs regularly.

\section{Limitations}

In our study, we did not take into account other contributors to sleep problems, such as stress and environmental stress factors, including noise and lifestyle. The fact that our study did not demonstrate a significant impact of diabetes on sleep disorders was probably due to the insufficient representation of diabetic patients.

\section{Conclusion}

Insomnia in the group of members of the University of the Third Age in Stargard coexists with chronic diseases, such as hypertension, asthma/COPD, atherosclerosis and depression. 
Source of funding: This work was funded by the authors' resources.

Conflict of interest: The authors declare no conflict of interests.

\section{References}

1. Szelenberger W, Jakitowicz J. Bezsenność - problem diagnostyczny i terapeutyczny. In: Szelenberger W, Nowicki Z, eds. Zaburzenia snu. Diagnostyka i leczenie, wybrane zagadnienia. Kraków: Komitet Redakcyjno-Wydawniczy Polskiego Towarzystwa Psychiatrycznego; 1999: 19-31.

2. American Psychiatric Association. Diagnostic and Statistical Manual of Mental Disorders. 4th ed. Washington: American Psychiatric Association; 1994.

3. Heitzman J. Zaburzenia snu - przyczyna czy skutek depresji? Psychiatr Pol 2009; XLIII(5): 499-511.

4. Manocchia M, Keller S, Ware JE. Sleep problems, health related quality of life, work functioning and health care utilization among the chronically ill. Qual Life Res 2001; 10(4): 331-345.

5. Cusack S, Rose Day M, Wills T, et al. Older people and laxative use: comparison between community and long-term care settings. Br J Nurs 2012; 21(12): 711-717.

6. Dudzińska M, Zwolak A, Neć M, et al. Polipragmazja - istotny problem w codziennej praktyce lekarskiej. Fam Med Prim Care Rev 2015; 16(3): 222-224.

7. Sobów T. Niebezpieczeństwa polipragmazji w neurologii. Post Nauk Med 2010; 23(6): 483-491.

8. Jarczewska DŁ, Krztoń-Królewiecka A, Widnak A. Pierwotne zaburzenia snu u osób w wieku podeszłym. Lek Rodz 2013; 18(6): 398-409.

9. Siemiński M, Potocka M, Karwacka M, et al. Bezsenność i stosowanie leków nasennych wśród osób starszych przebywających w domach opieki. Sen 2006; 6(2): 54-57.

10. Lineberger MD, Carney CE, Edinger JD, et al. Defining insomnia: quantitative criteria for insomnia severity and frequency. Sleep 2006; 29(4): 479-485.

11. Westerlund A, Bellocco R, Sundstrom J, et al. Sleep characteristics and cardiovascular events in a large Swedish kohort. Eur J Epidemiol 2013; 28(6): 463-473.

12. Błaszczyk R, Wysokiński A, Ciota M, et al. Zaburzenia snu oraz senność dzienna u pacjentów z nadciśnieniem tętniczym. Pol Prz Kardiol 2010; 12(2): 109-115.

13. Pracka D, Pracki T. Chronobiologia rytmu sen-czuwanie. Sen 2002; 2(Supl. 2): A7-A12.

14. Matthews K, Kamarck T, Hall M. Blood pressure dipping and sleep disturbance in African-American and Caucasian men and women. Am J Hypertens 2008; 21(7): 826-831.

15. Maury E, Ramsey KM, Bass J. Circadian rhythms and metabolic syndrome: from experimental genetics to human disease. Circ Res 2010; 106(3): 447-462.

16. Roepke SK, Ancoli-Israel S. Sleep disorders in the elderly. Indian J Med Res 2010; 131: 302-310.

17. Bujnowska-Fedak MM, Sapilak B, Steciwko A. Epidemiologia chorób w praktyce lekarza rodzinnego - najczęściej spotykane problemy, najczęściej rozpoznawane schorzenia, ranking TOP TWENTY-badania pilotażowe. Fam Med Prim Care Rev 2009; 11(3): 251-254.

18. Laposky AD, Bass J, Kohsaka A, et al. Sleep and circadian rhythms: key components in the regulation of energy metabolism. FEBS Lett 2008; 582(1): 142-151.

19. Tsujimura T, Matsuo Y, Keyaki T, et al. Correlations of sleep disturbance with the immune system in type 2 diabetes mellitus. Diabetes Res Clin Pract 2009; 85(3): 286-292.

20. Kinalska I, Popławska-Kita A, Telejko B, et al. Otyłość a zaburzenia przemiany węglowodanowej. Endokrynol Otył Zab Przem Mat 2006; 2(3): 94-101.

21. Bidzan L. Zaburzenia snu w wieku podeszłym. Geriatria 2011; 5(1): 34-40.

22. Skalski M. Wybrane zagadnienia z medycyny snu. Fam Med Prim Care Rev 2009; 11(3): 750-756.

23. Lau K, Jośko J. Zaburzenia snu jako problem zdrowia publicznego. Zdr Publ 2010; 120(2): 199-202.

24. Ohayon MM, Roth T. Place of chronic insomnia in the course of depressive and anxiety disorders. J Psychiatr Res 2003; 37(1): $9-15$.

25. Jakitowicz J, Nitka A, Orłowska-Kunikowska E, et al. Zaburzenia snu i objawy depresyjne u chorych hospitalizowanych z powodu cukrzycy. Sen 2002; 2(4): 121-126.

26. Plantinga L, Rao MN, Schillinger D. Prevalence of self-reported sleep problems among people with diabetes in the United States 2005-2008. Prev Chronic Dis 2012; 9: E76.

27. Cunha MC, Zanetti ML, Hass VJ. Sleep quality in type 2 diabetics. Rev Lat Am Enfermagem 2008; 16(5): $850-855$.

28. Piwoński J, Piotrowski W, Prejbisz A. Prevalence of insomnia in the Warsaw metropolitan area (Pol-Monica-Bis) - relationship to hypertension and other cardiovascular risk factors. J Hypertens 2003; 21(1): S171.

29. Błaszczyk R, Wysokiński A, Ciota M, et al. Zaburzenia snu oraz senność dzienna u pacjentów z nadciśnieniem tętniczym. Pol Prz Kardiol 2010; 12(2): 109-115.

30. Ohayon MM, Roth T. What are the contributing factors for insomnia in the general population? J Psychosom Res 2001; 51(6): 745-755.

31. Chrzan R, Kulpa T. Bezsenność jako problem pacjentów geriatrycznych hospitalizowanych z powodów chirurgicznych - doświadczenia własne. Fam Med Prim Care Rev 2010; 12(2): 152-155.

Address for correspondence:

Weronika Wolińska, MSc

Zakład Nauk Humanistycznych w Medycynie PUM

ul. Chłapowskiego 11

70-103 Szczecin

Polska

Tel.: +48 508 301-892

E-mail:weronika.wolinska@pum.edu.pl

Received: 31.03.2016

Revised: 24.05.2016

Accepted: 27.06.2016 